\title{
Reflecting on the Margins: Socio-spatial Stigmatisation among Adolescents in a Peripheralised Region
}

\author{
Frank Meyer, Judith Miggelbrink, Tom Schwarzenberg
}

\begin{abstract}
Based on the project "Discourse and practices in shrinking regions", we analyse the subjective relevance of derogative discourses using the example of the district of Altenburger Land (Germany). The article combines three aspects: First, it focuses on how young people's representations of practices of social differentiation are informed by regionalised discourses about and conditions of shrinkage. Second, it identifies two rhetoric strategies by which young people distance themselves from perceived deviance. Finally, it asks how perceptions and rhetoric strategies are connected to desires to out-migrate. We assume that stigmatisation is a powerful means of producing and circulating socio-spatial differentiation, especially under conditions of socio-economic crisis and deprivation. Our principal hypothesis is that socio-spatial stigmatisation is effective (and destructive) in terms of how people perceive themselves within their home region, in relation to other inhabitants and regarding their prospective future plans. In order to address this aspect methodologically, we compose an epistemological framework to grasp how socio-spatial stigmatisation is articulated and circulates in the light of specific socioeconomic conditions. Here, we conceptually draw from social psychology and social geography. Our empirical findings, which stem from a series of focus groups, show that - while sharing some widely spread notions about the Altenburger Land - our respondents make use of two rhetoric strategies: They deflect derogative stigmas by, firstly, further specifying these groups in order to distinguish themselves from the stigmatised groups, and, secondly, by localising deviant behaviour within almost uncontested socio-spatial boundaries. Additionally, they construct causal connections between these aspects in order to re-affirm the validity of such stigmas.
\end{abstract}

Keywords: Shrinkage · Stigmatisation · Peripheralisation · Identity · Group-focused enmity 


\section{Situating stigmatisation geographically: Shrinking regions in Eastern Germany}

Discursive phenomena with regard to peripheralisation have long been neglected and are still deliberately left out of relevant studies (e.g. Kühn 2015: 369). However, questions addressing entwinements of material and discursive phenomena have emerged in the wake of the recent rejuvenation of the debate about peripheralisation. In this context, several scholars advocated elucidating discursive dynamics (e.g. Barlösius/Neu 2008), processes of labelling (Beetz 2008) and subjective perceptions and reactions in practice following spatial representations related, for example, to shrinkage (Meyer/Miggelbrink 2013, 2015).

Contemporary scholars have elaborated the presence of such territorial stigmatisation with regard to socio-economic marginality, peripheralisation or shrinkage. Moreover, some of the same have underlined the necessity to include this discursive dimension, such as place- and group-related labelling, into the research of marginality, peripheralisation or shrinkage (Beetz 2008; Meyer/Miggelbrink 2013) as labelling may inflict - when exerted in derogative ways - considerable damage. Numerous studies (e.g. Wacquant 2007; Dando 2009; Bürk 2013; Wiest 2015) have emphasised that circulating stigmas find their way into the lives and practices of individuals and groups within the addressed regions, cities and communities, eventually influencing the ways they make sense of their surroundings. In consequence, these perceptions can lead to several reactions such as opposition or resignation (Bürk 2013) and thus are able to catalyse or mitigate prevalent socio-economic precarity. Moreover, labels may also be incorporated into everyday communication within the respective region. They may be proliferated, intermediated and altered in complex and interactive ways. The perception and reflection of stigmatisation can thus lead to further social stigmatisation within the region addressed and fuel existing processes of negotiating identities, life courses and norms. In other words, stigmatisation is an efficacious process exerting influence in several social contexts, guided by (biased) proliferation, (selective) perception and (subjective) interpretation. The empirical data available so far remains ambiguous regarding precise accounts at the subject level. Our focus lies on tracing the effects and the paths of the reproduction of socio-spatial stigmatisation within those groups potentially affected by the respective stigmas. Arguing against any reductionist causal assumptions about socio-spatial stigmatisation determining people's mentality, self-awareness and attitudes against others, we instead advocate using a conceptual focus that investigates the roles of socio-spatial representation within subjectively perceived everyday life.

Therefore, our own focus for understanding impacts of stigmatisation will be twofold. On the one hand, we address how existing socio-spatial stigmatisation in young people's perceptions is related to denigrating attitudes, i.e. how territorial stigmatisation coincides with derogative statements against other people or groups. On the other hand, we focus on possible impacts of stigmatisation on how young people imagine their own future in terms of leaving or staying in their home region, i.e. their potential migratory decisions. At first glance, this might be considered two different questions. However, we will argue theoretically as well as prove 
empirically how both attitudes towards certain groups or people and consideration on future decisions concerning "staying or leaving" are intertwined in young people's reflections on representations of their home region.

We want to pursue this aim through a discussion of a social-geographical approach towards young people's perception of their hometown and region. The socio-geographical, socio-psychological and sociological embeddedness of our research are discussed in section 2. Our empirical data consists of 15 focus groups with pupils of secondary schools within the German district of Altenburger Land. ${ }^{1}$ From 1998 to 2014, the population of this Thuringian district decreased from 117,000 to roughly 98,000 people, a decline of more than 20 percent. Moreover, the population between the ages of 15 and 18 dropped by more than 57 percent. The Thuringian Statistical Office projects that these developments will continue in similar ways at least until $2035 .^{2}$ Based on the alleged everyday presence of these remarkable figures and the possibility that discussions may focus too much on them, we avoided mentioning the population development ourselves. Instead, our conversations aimed at gathering the adolescents' orientations towards their home region and their future plans. However, it soon became apparent that these focus groups - despite our original thematic intentions - revealed strong negative opinions about the district of Altenburger Land, reproducing derogatory representations about the region and its inhabitants. These findings are discussed in section 3 . The concluding section 4 summarises our main results and discusses them against the background of our theoretical and conceptual assumptions.

\section{Theoretical perspectives on stigmatisation, disintegration and perceived devaluation}

\subsection{Spatial formation and the role of territorial stigmatisation}

Social geographers have underlined the necessity to understand the formation of regions and cities as being relationally produced through a multitude of processes that neither originate from the respective place nor are immutable and stable (see Massey 1993; Paasi 2013). Amin (2004: 34), for instance, states that

"...cities and regions as spatial formations (...) must be summoned up as temporary placements for ever moving material and immanent geographies, as 'hauntings' of things that have moved but left their mark (as Thrift (1999) puts it), as situated moments in distanciated networks, as contoured products of the networks that cross a given place."

1 The research was carried out under the auspices of the project "Discourse and practices in shrinking regions", funded by the German Research Foundation (2013-2016, MI725/2-1).

2 All figures: Statistical Office of Thuringia 2015: http://www.statistik.thueringen.de/. 
"Temporary placements", thus, not only emerge through physical structures and their remnants but also through circulating gossip, stories and memories. Placerelated images and stigmas, as Shie/ds points out (1991), are always part of national and cultural systems of meaning. Hence, images and stigmas can be seen as generated within discursive frames based on what Weichhart et al. (2006: 98-99) describe as cognitive structures of place-related identity formations. These formations - entangled at the intersection of both individual and group-related concepts of place and identity (Weichhart et al. 2006: 37) - serve to stabilise social systems by reducing social complexity as well as establishing consistency (Weichhart et al. 2006: 61-63). Following this notion, spatial categories like regions and cities are not only discursively and thus temporarily identified but also consistently identified with. Such assumed constitutive interrelations between (socio-psychological) aspects of identity and (socio-geographical) concepts of space can be seen as crucial insights when looking at stigmatisation.

Coming from a sociologist's perspective, Wacquant (2007) similarly conceptualises territorial stigmatisation as part of "advanced marginality" meaning that grouprelated stigmas associated with poverty, for example, may also entail a more general "blemish of place" (Wacquant 2007: 67). Spatial and social aspects of stigmatisation therefore need to be considered as inseparably intertwined (Cohen 2013: 116). Consequently, focusing on socio-spatial stigmatisation calls for a perspective that is sensitive to the mediating role of space, i.e. a perspective that expands its analytical and empirical scope to encompass not only processes of social identification of places, individuals and groups but, moreover, their mutual impacts.

Drawing on these foundations, Bürk has defined stigmatisation as an act of communication-based construction (Bürk 2013: 171). Using the example of perceived "danger zones" or "spaces of fear" (Bürk 2012), he refers to "discursive formations" that scandalise specific locally significant and negatively connoted issues like unemployment, drug abuse or crime and utilise certain "iconic markers of urban decay" (Bürk 2013: 171). Those "symbolic frames of stigmas" provide the stigmatised social group with a thematic spatial reference (Bürk 2013: 171). Hence, such frames can be understood as semantic fields that powerful actors make use of in order to influence the perception of groups and places through subtle processes of sociospatial labelling (Bürk 2012: 91). However, Schreiber acknowledges that spatially ascribed meanings have neither a causal effect, nor are invariable, but are rather the products of the discursive production of knowledge (Schreiber 2005: 86). Hence, stigmatisation can be regarded as outcomes of socially - and as such discursively - constructed derogative categories, distinguishing and demarcating spaces and groups of people.

Images and stigmas ascribed to places are often intimately linked to symbolic orders and categorisations such as "high/low" or "central/marginal" (Shie/ds 1991: 4) imposing productive as well as destructive capacities on people, practices and policies. However, this is, of course, not a relationship of cause-and-effect. In order to tackle the complexities of how (certain) people, practices and policies are affected by ascribed place-related images, stereotypes and stigmas and how they deal with 
them specifically in a non-deterministic way, we see the necessity to go beyond narrow disciplinary boundaries.

The foundation of this field of research is inextricably linked to the American sociologist Erving Goffman who has generally defined a stigma as "[...] an attribute that is deeply discrediting [...]" (Goffman 1974: 4). A stigma often - though not necessarily - takes bodily markers or physical characteristics as signifiers by which people are identified as belonging to a certain group, category or kind. According to Goffman, characteristics ascribed to a person or a group may constitute a "virtual social identity" (Goffman 1974: 3). Those ascribed characteristics often differ significantly from a so-called "actual social identity" (Goffman 1974: 3).

Implicitly or explicitly emerging from social norms and a hegemonic understanding of normality, such categories are based on deviance. With specific regard to stigmatisation, Hohmeier (1975: 11) points out the use of a deviant "other" as the foundation for constructing normality. This thought indicates a vast relativity of the concept of normality, since one person's stigma can be another person's normality and vice versa (Goffman 1974: 4). However, this conceptual ambiguity serves - as Klauer states - to simplify heuristics of perceiving and to assess the complexity of the social (Klauer 2008: 23-24). Bearing this mode of simplification in mind, Hannem and Bruckert have highlighted the alluring nature of stigmas: "How can we, individually and collectively, resist stigma: resist the temptation to fall back on prevailing cultural stereotypes as shortcuts to interpreting the world around us?" (Hannem/ Bruckert 2012: 176). As we will show later on, we assume that although people often acknowledge the reifying and simplistic nature of stigmas (and often feel forced to defend them), they still work as shortcuts of the social world.

In the following sections, we deal with a number of arguments from sociology, social psychology and social geography carving out two main lines of reasoning. One (2.2) focuses on subjects' experiencing peripheralisation in terms of social, political and economic marginalisation (see PoSCoPP 2015). This presumably leads to (feelings of) disintegration and exclusion and, as a potential effect, brings about stigmatisation of other groups and places that are seen as being even "weaker", "lower" or "more problematic" than one's own peer group or one's own place. Here, we draw especially on the work of German social scientist Heitmeyer and others on group-related enmity. The other line of reasoning (2.3) refers to literature mainly from social psychology and aims at tracing individual and group-related effects on existing and widely circulating stigmas and stereotypes that people feel subjected to, especially under conditions of socio-economic crisis. Both strands refer to the concept of stigma located at the intersection of anthropological, social psychological and psychiatric studies of roles, expectations and deviant behaviour. In order to empirically investigate stigmatisations that are articulated during conversations with young people, we apply both strands of research: The first one helps to understand why "feeling stigmatised" and "stigmatising others" often coincide under precarious conditions. The second one illuminates potential coping strategies. 


\subsection{Stigmatisation and devaluation as symptoms of disintegration}

We will first have a look at the literature on stigmatisation in the context of socioeconomic crisis. Conceptual groundwork concerning this context can be found in the analytical theory of disintegration by Wilhelm Heitmeyer and Reimund Anhut. They elaborated three distinct dimensions of social integration - namely individual-functional system integration, communicative-interactive social integration and cultural-expressive social integration - each of which are connected to corresponding integrative aims like participating in socially relevant subsystems, political and public institutions as well as socio-emotional relations (Anhut/Heitmeyer 2000: 48). Furthermore, following the notion of a distinct socio-spatial disparity concerning the accumulation of (dis)integration (Anhut/Heitmeyer 2000: 59), a fourth aspect - spatial integration - was subsequently pointed out, highlighting the possible influence of socio-spatial conditions on individual attitudes and behaviours (Heitmeyer et al. 2009: 3-4). Thus, a disruption in one or more out of these dimensions, i.e. the failure to meet the corresponding aims of social integration (Anhut/Heitmeyer 2000: 51-52), can be understood as disintegration in terms of a refused institutional and collective service to secure livelihood, social recognition and personal integrity (Anhut 2008: 381). Such disruptions tend to be intensified by framing social processes and phenomena of crises like polarisation, eroding solidarity or ambivalent individualisation, which can take on the form of social inequality, exclusion, feelings of injustice, lack of social support and/or social isolation (Anhut 2008: 381).

This conceptualisation of individual (dis-)integration is further used to illuminate the formation of conflicts that are articulated through derogative processes. Depending on the steering influence of moderating variables like political culture, social networks, social climate, political control or intergroup relations (Anhut/Heitmeyer 2000: 60), individual disintegration can indirectly nurture the desire to defend oneself against and devaluate the deviant other (Anhut/Heitmeyer 2000: 63). Thereby, one's own rejected institutional and collective perspectives on integration can likewise lead to withholding integration possibilities from weaker, marginalised groups (Heitmeyer et al. 2009: 2). More precisely, experiences of disintegration may cause irritation, thus leading to compensatory behaviour (Mansel/Kaletta 2009: 76-77). Empirical research has shown that this behaviour is often manifested as prejudices towards other groups (Mansel/Kaletta 2009: 76-77). Moreover, a lack of integration can coincide with an insufficient feeling of control, likewise inducing processes of devaluation (Mansel/Spaiser 2010: 51-53).

In sum, experiences and feelings of disintegration are considered breeding grounds for so-called ideologies of inequality (Mansel/Spaiser 2010: 74). "Ideologies of inequality" refers to the idea that humans are constantly differentiated in social groups and thereby implicitly evaluated through particular ascribed character traits (Heitmeyer 2008: 37) whereas inequality often becomes evident through the devaluation of certain groups (Heitmeyer 2008: 38). In his long-term study "Deutsche Zustände" (German Conditions), Heitmeyer considered this concept a key to understanding group-focused enmity as a syndrome that combines different forms of sometimes subtle, sometimes obvious devaluation based on the discur- 
sive legitimacy of inequality (see Heitmeyer 2006, 2012). Thus, it is necessary to differentiate between (unchallenged) disparities - in the sense of socio-economically grounded and normalised distinctions - and unequal valuations as a result of the semantic categorisation of those disparities (Heitmeyer 2008: 39-40). Hence, socioeconomic disparities are often loaded with ascriptions and negotiated against the background of a specific understanding of normality (Heitmeyer 2008: 39-40). The particular groups addressed may vary but are equally targets of (de)valuating communicative practices with regard to the thematic interests of those in charge of defining this label (Heitmeyer 2008: 39). This entails the phenomenon that in addition to "traditional" groups of victims, new stigmatised groups are continuously constructed on the basis of them not meeting expectations within societal discourse regimes (Heitmeyer 2008: 40).

Notwithstanding the fact that Heitmeyer did not employ the concept of "stigmatisation" in his investigation of group-focused enmity, his approach shows some parallels with findings from research on stigmatisation. Experiences and fears of disintegration as breeding grounds for ideologies of inequality allegedly give way to processes of stigmatisation. There is evidence, for instance, of a correlation between disintegration, unemployment, poor economic performance and a bad public image coinciding in rural regions in Eastern Germany (Mansel/Kaletta 2009: 73-74).

Petzke et al. (2007), for instance, have found a significant tendency towards group-focused enmity in rural areas of Eastern Germany struggling with severe outmigration. In this regard, they point out a negative dynamic due to observed conformist behaviour (Petzke et al. 2007: 60) and peer-pressure in those areas (Petzke et al. 2007: 68). Furthermore, Hüpping and Reinecke revealed that residents of regions struggling with economic decline are more likely to report a general uncertainty and loss of orientation as a result of negative experiences and perceptions (Hüpping/ Reinecke 2007: 80), while especially fearing social decline (Hüpping/Reinecke 2007: 95). These experiences and fears are understood as a structural basis for devaluating behaviour against other groups (Hüpping/Reinecke 2007: 95). They are further shown to be particularly strong among young people on the verge of their working life (Endrikat 2006: 108).

These predispositions are further served by what Wolf et al. (2006: 68) call "relative deprivation", i.e. a perceived discrimination resulting from comparing one's own situation with that of another person's or group's. These subjective comparisons are accompanied by compensatory devaluation of others (Wolf et al. 2006: 67). Therefore, individual deprivation is reinforced in the context of socio-economic crises, potentially resulting in an increased tendency towards misanthropic attitudes in the sense of group-focused enmity, as the authors of the study explicitly underline (Wolf et al. 2006: 82). Analogically, Decker et al. have shown that even the sole fear of becoming stigmatised and excluded due to economic deprivation (e.g. loss of employment) can nurture the willingness to devaluate marginal groups (Decker et al. 2009: 3).

In 2009, a study based on 500 telephone interviews carried out in the district of Altenburger Land proved how closely socio-economic peripheralisation, (dis)integration and group-related devaluation are related (Heitmeyer et al. 2009). Many of 
the local residents who feel strongly disintegrated in terms of labour market participation articulated fears of social and economic decline while expressing feelings of both individual and regional discrimination and deprivation (Heitmeyer et al. 2009: 13) which analytically correlate with group-focused enmity (Heitmeyer et al. 2009: 34). In addition, experiences of socio-emotional as well as spatial disintegration due to precarious employment opportunities have been documented (Heitmeyer et al. 2009: 20), likewise reinforcing a tendency towards group-focused enmity (Heitmeyer et al. 2009: 37). The study also diagnosed distinct individual disorientation and a perceived absence of local influence on the political level (Heitmeyer et al. 2009: $16-19,25)$ among the district's residents - both potentially nurturing misanthropic attitudes as described above (Heitmeyer et al. 2009: 41).

In sum, socio-economic aspects of peripheralisation echo at the psychological level of the subject: Experiences and fears of disintegration, whether they are articulated through a general uncertainty, a loss of orientation or a feeling of deprivation, have been revealed as particular conditions - though by no means determining factors - that fuel group-focused enmity and thus derogative practices in the sense of (socio-spatial) stigmatisation. As such, these processes of devaluation are by no means a mere causal or determined result of socio-economic conditions, but are rather a structuring and constitutive element of the social (Attia 2013: 4-5).

\subsection{Sociological and socio-psychological approaches to understanding experienced stigmatisation and its potential effects}

Stigmas are understood as easily becoming unchallenged, ultimately leading to a sense of social and spatial phenomena that matches one's expectation and may resist empirical adjustment (Greitmeyer 2008: 80). Thereby, stigmatising representations contribute to the consolidation of the reality they symbolise (Howarth 2002: 250) and become persistent. Using Goffman's vocabulary, the gap between a virtual and actual social identity becomes increasingly hard to dissolve. Since those discursively sedimented practices of devaluation are intertwined with spatial labelling processes, the negative ascriptions concerning related places may likewise become persistent. Bürk underlines that once certain labels and frames find their way into popular discursive regimes it is very difficult to replace them (Bürk 2012: 91). Very often then, stigmatised people are in fact not the bearers of the stigma anymore, but rather act as representatives of a stigmatised region (Bürk/Beißwenger 2013: 128). Wacquant (2007: 68) therefore concludes:

"Whether or not these areas are in fact dilapidated and dangerous, and their population composed essentially of poor people, minorities and foreigners, matters little in the end: the prejudicial belief that they are suffices to set off socially noxious consequences."

However, as stigmas have been subject to different disciplines, understandings of how they allegedly affect people and places differ remarkably according to theoretical and methodological approaches to the social and the psychological. In its broadest understanding, a territorial stigma equals a poison permeating everything. 
In his seminal study of the American ghetto, Wacquant highlights the general presence of a "symbolic taint and territorial stigmatisation, contaminating every area of social endeavour, from friendship and housing to schooling and jobs" (Wacquant 1997: 346). The potential of stigmas to reach a state of omnipresence is considered one of the "structural and strategic constraints that bear on the racialised enclaves of the city as on no other segment of America's territory" (Wacquant 1997: 346). Analogically, in her study of adolescents in a stigmatised South London community Howarth underlines that

"(h)ow others recognize us has an impact on how we recognize ourselves. This is particularly true for the adolescent. [...] For those from marginalized and stigmatized communities, the gaze of the other is all the more inescapable." (Howarth 2002: 240)

However, not every stigma exerts such severe influence. Some stigmas may be ignored, some may not be perceived at all and some may be reflected only within certain epistemic groups.

Coming back to socio-spatial stigmatisation, nevertheless, the omnipresence - and thus hegemonic nature - of a territorial stigma does not "simply" mean a communicative demarcation of the region, city or quarter in question but has real consequences for those who feel the stigmatising gaze settled on them, for example local residents. "When a child grows up in a stigmatised neighbourhood [...], the socio psychological consequences of such neglect can be severe" (Howarth 2002: 251). This mode of rejection may inflict psychological strain and, thus, interfere with the (re)construction of identity (Howarth 2002: 249) up to the point where "for those stigmatised, questions of identity are painfully inescapable" (Howarth 2002: 246). In the same line of reasoning, Schooler et al. (2004) argue that a stigma can become relevant for self-identification when an individual imagines her or himself as a member of a stigmatised group. Membership, in turn, is based on preceding and repeatedly performed social categorisation and identification. For instance, when it comes to impacts of idealised body images in mass media, "(a)s fellow members of a stigmatised group (Crocker/Major 1989), Black women may see other Black women as allies, not as competitors, and may therefore find comparisons with other Black women, even with ideal media images, inspiring" (Schooler et al. 2004: 44). Feelings of belonging to a certain group might thus be based on ethnic, racial, age or gender-related signifiers but could also refer to a shared socio-territorial abode. However, the fact that one considers oneself - sometimes subconsciously - part of the group addressed may lead to certain reactions.

An important strand of socio-psychological research to which we refer has tackled the question on how far experiences of belonging to a stigmatised group have an impact on a person's self-esteem (e.g. Crocker/Major 1989; Crocker 1999; Camp et al. 2002; Major et al. 2003) and are related to objective self-awareness (e.g. Pinel/ Bosson 2013). Studies in this field have underlined that there is no linear or causal relation between stigmatisation and low self-esteem as one would probably expect. Instead, Crocker and Major and, later on, others have argued that people who identify as members of a stigmatised group often feel uncertain whether a certain 
reaction to them is due to their individual abilities or behaviour or due to generalised expectations deriving from stigmatisation. This "attributional ambiguity" (Crocker) Major 2003 refering to Crocker/Major 1989) may cause positive as well as negative feedbacks in terms of self-esteem. Consequently, situational aspects and "stigma consciousness" (Pine/ 1999) play a crucial role in this debate. Pinel and Bosson (2013: 56), for instance, emphasize that "stigma-relevant components of social identity may or may not attract one's attention" depending on whether the respective component is scorned or esteemed in a certain situation (e.g. gay identification in a homophobic environment versus gay identification in the context of a Gay Pride event).

Thus, being stigmatised does not necessarily undermine self-esteem. Based on an observed lack of difference in the level of self-esteem between stigmatised and non-stigmatised groups, it has been discussed that blaming the stigma - i.e. attributing negative outcomes to existing stigmas and stigmatisation - may serve as a protection for one's self-esteem. “When prejudice is overt, people blame negative outcomes on discrimination rather than themselves, and their self-esteem is buffered as a result of this discounting process" (Major et al. 2003: 229). Furthermore, self-esteem can be protected by "paradoxical contentment" (Crocker/Major 2003: 233), i.e. "the tendency to make in-group social comparisons and the tendency to devaluate certain domains that one's group doesn't tend to succeed in might also protect self-esteem" (Crocker/Major 2003: 233). Thus, stigmatisation does not necessarily have an impact on people in terms of lowering self-esteem or undermining self-awareness.

In addition, it has been observed that people who apply a stigmatising representation to themselves tend to play down or even negate their ties to the stigmatised group in question and thereby potentially devaluate elements of their social identity (e.g. Howarth 2002: 250). For instance, people living in a stigmatised area may claim to be different from the object of stigmatisation, invoking - in a deflecting attitude - a certain social difference or distance between those "rightfully" stigmatised and themselves (Howarth 2002: 251). This in turn can paradoxically lead to further devaluating practices within the originally labelled region. Based on the arguments above, these acts can be interpreted as coping strategies in order to preserve selfesteem.

In sum, we claim that studies from social psychology contradict popular notions of stigmas as externally introduced labels negatively affecting people - a notion that is nevertheless common within the fields of politics. Instead, stigmatisation has to be understood as a regime consisting of discursive and embodied practices of labelling an entity in potentially devaluating ways and thus affecting both the relationship the person addressed builds to her or himself as well as relationships to others. This notion allows for the possibility of alterations - intentional or not - and acknowledges the dimension of social negotiation. As such, stigmatisation has to be seen as a highly complex, multi-lateral social phenomenon that is able to exert considerable influence on various aspects of human behaviour. 


\subsection{Socio-spatial stigmatisation and out-migration}

This leads us to the question, if and to what extent the structuring power of stigmatisation materialises in (young) people's decisions to out-migrate. Besides analysing the impact of stigmatisation on self-esteem and on devaluating attitudes against others, studies of coping with stigmatisation have also discussed the role of sociospatial stigmas in (young) people's decisions to out-migrate. Though not assuming a determining, causal relationship, studies on peripheralised rural regions or rural regions under depopulation pressure in particular have repeatedly postulated close links between stigmatisation and out-migration (Wiest 2015; Wiest/Leibert 2013; Wiest 2015). Referring to Kühn and Weck (2013) and Beetz (2008), Wiest (2015: 2) writes, "the stigmatisation of areas due to the production of negative self and public images must be treated as an important aspect since negatively connoted semantics not only have a descriptive character, but also produce relevant expectations that have an influence on human behaviour." A regional narrative of out-migration has become so dominant that - as Wiest (2015: 2) assumes - the "fear of missing the boat and being left behind" leads to a situation in which "staying in a home region is no longer taken into a young person's consideration". If socio-spatial stigmatisation is both an outcome of social marginalisation and exclusion and can be seen as a medium through which marginalisation and exclusion are performed, out-migration could be regarded as a logical consequence that is already included in local narratives.

Out-migration furthermore involves the negotiation of socio-spatial identities (Jones 1999). The cumulative and mutually boosting impacts of omnipresent ascriptions, feelings of being identified by stigmatisation in processes of social and discursive reproduction are conveyed by the term "culture of out-migration" (Wiest 2015: 6). Although this notion of "culture" may have an essentialist undertone, it serves to point out a discursive regime as a subjectively shared socio-symbolic order of knowledge produced and reproduced through everyday actions, perceptions, emotions and decisions. We assume the (re-)production of regional images of out-migration to be a decisive element of how potential decisions to out-migrate are negotiated.

\section{Socio-spatial stigmatisation among adolescents: Empirical findings}

\subsection{Dissecting logics of stigmatisation: Methodological notes}

To specify the methodological embedment of our empirical findings it seems necessary and useful to reflect on the main reasons that we initially selected the Altenburger Land district as a case study region. For one thing, it mirrors a set of criteria applied to a sample of German districts that are characterised by persistent problematisations with regard to socio-economic parameters such as purchasing power, unemployment, out-migration and a significant demographic shift towards an aging population (see e.g. BBSR 2015: 8). But more decisively - bearing in mind our 
epistemological focus on discursively negotiated (negative) representations - Altenburger Land is constantly identified as a "problem-region." For instance, experts' interest in its demographic development can be observed. The district has become the subject of political programmes aiming at countering population decline and marginalisation. Regarding media coverage, the case study region has persistently received bad results in so-called regional rankings (e.g. IWConsult 2014). Such representations mainly focus on the aforementioned socio-economic criteria and draw on conditions of shrinkage, but - as stigmas - also involve further criteria of social deviance. This situation is, however, not specific for this district but applies to a number of other regions facing the same demographic and economic challenges both in Germany and beyond its borders. Based on focus groups with adolescents from Altenburger Land, we aim at witnessing how such conditions of stigmatisation inform adolescents' modes of social differentiation.

Stigmatisations, as we have shown above, not only affect individuals in terms of self-awareness and may influence individual decisions widely regarded as "personal", but also have further structuring effects on social and inter-group relations. Researching stigmatisation, thus, raises methodological issues concerning the full range of circumstances in which stigmatising moments as well as potential effects and the ways both are related through practices can be observed (see Miggelbrink/ Meyer 2015a). Hacking argues that external ascriptions, for example by institutions, experts or a general regime of knowledge (Tekin 2014: 240), are indeed perceived and reflected by the respective person addressed and that, as a consequence, we may notice not only changes in the respective subject's self-concepts but also behavioural changes known as looping effects (Hacking 1995). The "effects of stigma on the self", as Crocker (1999: 91) more generally puts it, are negotiated, created, and acted upon in the situation. Although Hacking remained quite ambiguous about the precise subjective processes, conclusions have to be drawn for research on stigmatisation as socio-spatial phenomenon. We consequently have to involve not only representations, their respective sources and the subjective reactions, but should incorporate insights into the changing practices of the addressed subjects (see Meyer/Miggelbrink 2013). Moreover, we by necessity have to be sensitive to the ways these subjects constitute their actuality:

"However, thinking through what people do, it can be seen that these positionings are not necessarily articulated, nor even articulable. They are therefore better witnessed, better understood through the ways in which people produce or turn over places and spaces for their own uses." (Pile 2008: 201)

Focusing on these subjective reactions in practice - and more specifically in the context of peripheralisation - undoubtedly entails an epistemological as well as methodological shift. Given that peripheralisation as social phenomenon can only be understood by incorporating socio-economic as well as discursive criteria (Beetz 2008: 13), researchers have to take their own dual nature into consideration: (1) With regard to the fact that empirical social research often makes use of reactive methods (such as: interviews of varying nature, focus groups), methodologies have to be elaborated that aim at dissecting the traces of socio-spatial representations 
(such as stigmatisation) from the respondent's statements (see Miggelbrink/Meyer 2015a; Schwarzenberg 2016) and focus on the role of stigmatisation on the respective decision-making process - of whatever rational or irrational nature it may be. (2) Given that shrinkage-related topics are highly influenced by scientific knowledge production (e.g. in the form of policy counselling), forming the basis for spatial representations and supposedly co-informing stigmatisation, scientific observers should acknowledge their own impact on this field of research and adjust their methodologies accordingly (see Miggelbrink/Meyer 2015b).

Drawing on the aforementioned conceptualisations of stigmatisation, groupfocused enmity, disintegration as well as subject theory, we conclude that sociospatial stigmas are collectively shared representations of groups and/or places. They are informed by assumptions about normality and deviance, of generalising and derogative nature and devaluate the ascribed entities. From a constructionist point of view, such deviance can, however, not be attributed to concrete behaviour, but refers to overlapping subjective and collective notions of what is regarded as normal. Furthermore, stigmatisation as an interactive process cannot be reduced to unilateral processes of labelling but instead has to be understood as socially negotiated floating semantics, potentially prone to perception, reproduction but also irrelevance. Those aspects may bear importance for those ascribed according to the respective subjective significance.

Methodologically, we conducted 15 focus groups with pupils from intermediate and upper secondary schools as well as vocational schools in the district Altenburger Land - most of them between the ages of 15 and 19. Under the supervision of one teacher, we talked about their perception of their home region and their future plans, with conversations lasting up to roughly 90 minutes. Afterwards, additional interviews with the respective teachers were conducted in order to contextualise the pupils' statements. Given the respective school-related and organisational constraints, the focus groups consisted of 5 to 25 pupils. Therefore, usually two moderators organised the discussion while the teachers remained in the background and were only occasionally active. After transcription and anonymisation, the conversations were codified within the software MaxQDA in order to inductively elaborate central concepts.

However, stigmas were rarely precisely explicated. Remarkably, although many of our respondents highlighted the presence of certain stigmas and stressed their artificial nature, they still - when describing their own perception of the district Altenburger Land - tended to stick to those same logics. Moreover, our respondents usually did not distinguish between collective representations (such as misfit's quarter), subjective perceptions (such as perceptions of drunk people) and statistical data (such as a high number of unemployed people within a given area). Only occasionally did some discussants mention that a place's image may not entirely fit their respective perception of it.

Consequentially, this had analytical implications for our study. For every quote and particular derogative ascription in relation to groups or places, we had to elaborate whether specific collective representations were used, for example by searching for generalising assumptions, claims about collective notions, etc. If, however, 
no indication of such direct adoptions of stigmas were present, we continued to look for statements that used specific descriptions in a similar manner, subsequently leading us to the conclusion of shared representations. During our focus groups, we usually left acts of stigmatisation uncommented. Occasionally, our respondents used paradoxical descriptions of the situation (e.g. when complaining about today's youth, despite being that youth). Such incidents provided us with the opportunity to dig into the processes of negotiation, explicate implicit assumptions and problematise the emergence and usage of stigmas.

In the following sections, we will dissect several stigmas that proved to be of importance across most of our focus groups. Although our conversations took place all across the district, in different school types and also in different age groups, we were able to distinguish a number of narrative strategies - namely deflective strategies of specification and localisation - involved in the reproduction of stigmas that are applied when young people talk about deviant behaviour, despised areas and about their own future prospects. Although they do represent adolescents' sensemaking of their surroundings, they do not necessarily coincide with actuality. Yet, they do provide traces of stigmatisation prevalent in the region. Firstly, we aim at elaborating stigmas regarding their ascribed characteristics and the respective places associated with them as well as their connection to the socio-economic circumstances of the Altenburger Land district. In a second step, we assemble common patterns of localised social deviance and its emergence and then, in a third step, we illuminate the impact of such representations on migratory decision-making. ${ }^{3}$ Such a systematic account, however, runs the risk of reducing the communicative complexity involved. The stigmas we identified share common patterns and permeate each other to some extent. We decided to especially include those stigmas drawing (1) on a common notion of deviant behaviour and (2) on notions of a proper way of life under conditions of shrinkage.

\subsection{Dystopian representations: Narrative fragments on the city and district of Altenburg}

During quite a number of group discussions, we were confronted with narrative fragments evoking the idea that either the whole district of Altenburg or the city of Altenburg or at least parts of it are highly problematic, disgusting places beyond what is going on elsewhere. In a longer discussion about "today's youth", a number or respondents - though themselves belonging to this age-group - draw a negative picture of young people in the city of Altenburg as smoking cigarettes and pot, drinking alcohol and consuming crystal meth (methamphetamine), even in front of the school. Later on, one of them shows that he is convinced these problems are specific for Altenburg:

3 The sources given for the statements relate to transcripts of the audiotaped conversations The respective sources refer to focus groups (FG_x), for which the specific cipher and position within the transcript is given. 
"There are too many prepubescent adolescents in the city of Altenburg who think they have to impress others. Of course, there are some cool people as well. [...] But there are also some folks that you wouldn't want to meet again. [...] They behave in pretty disgusting ways. And if there is something they don't like, they'll totally freak out. That's Altenburg; it's not in every city." (FG_21:455)

Accordingly, a classmate expresses relief that "we don't live in the city of Altenburg" (FG_16:466ff.), seconded by a third student who offers a clarification for the moderator, "To put it this way: We think of ourselves as being relatively normal. But there are these others." (FG_16:466ff.)

In a nutshell, these and similar quotes present narrative elements that were repeatedly used throughout our discussions. First, narratives frequently employ visual arguments to illuminate the precarious conditions of the respective region, town or village. What is regarded as problematic materialises in people and places that exhibit the problem and, in turn, places and behaviour that are identified as differing from normality and thus serve as an indicator of the bad condition of the whole socio-spatial entity. A second, more specific narrative topic unfolds around drugs and drug abuse. Although this topic is difficult to grasp and thus to validate using "official" figures, almost all people we talked to during our research - including experts in the field of drug prevention - assured us that the consumption of crystal meth is a rising problem in Altenburger Land. Drugs - alcohol and crystal meth were regularly mentioned - are the epitome of what is considered "problematic", "bad" or "deviant" with regard to people and places here. Altenburg, in turn, is considered the epitome of drugs:

"The stronghold of drugs! Just go anywhere, Leipzig or Gera: Where do you come from? The city of Altenburg! Altenburg is associated with drugs. People know what's going on here." (FG_23:441)

Although this perception is not devoid of any empirical evidence in terms of quantitative numbers (e.g. Härtel-Petri/Haupt 2014), pupils use the topic primarily to underline the rather dystopian nature of the city of Altenburg and even the whole region as the quote above demonstrates. Moreover, pupils feel they are perceived by outsiders through the lens of this widely known image of the region that is directed as stigma on them. One might ask if drugs are an arbitrary marker to both indicating the current situation and building the image of the region (e.g. Haegeler 2015), however, it was the marker used through almost all group discussions. Drug abuse was one of the recurrently applied markers of difference - despite the fact that few of our respondents were assumed to take drugs themselves, as teachers mentioned in feedback interviews. And drug abuse was one of the recurrently applied markers of the image of the region people from outside are assumed to have. Moreover, we found several strategies to somehow encircle the problematic elements and locate

4 The quotes from the focus groups were translated by us. The German versions have been amended. 
them e/sewhere - both in terms of locating them at "another" place or associating them with "other" people and groups. In the following section, we concentrate on this strategy.

\subsection{Encircling stigmas: Deflective strategies of specification and localisation}

\subsubsection{Students in intermediate secondary schools}

Among those in upper secondary schools (Gymnasium), our respondents often applied a deflective strategy of specification, used to transform a very general pejorative label for the regional population into a more specific stigma for the group of pupils on the intermediate level of secondary school education (in contrast to the upper secondary education: the Gymnasium):

A: And the Förderschulen [special schools] get closed so the Förderschüler learn with the Regelschüler [pupils in intermediate secondary education], and everything becomes even more catastrophic. [...] Occasionally, we have physical education together - how they talk the teachers down!

Moderator: [...] So what's the difference between Regelschule and Gymnasium? Talking teachers down?

B: That - at first - and second, the Regelschule is really asocial. There are exceptions, but only a few. Most of them are really asocial, swearing at each other. There are fights quite often. (FG_17:441ff.)

Widely shared notions of school type-specific deviance serve the practice of reinforcing social boundaries already introduced by the German school system. Being federally organised, the 16 different school systems in Germany (and the corresponding terminology for the respective school types) usually distinguish between different levels of performance but are often seen as reproducing social inequalities to a certain extent (e.g. Schneider 2008). Evidence has been found of Germany-specific effects of tracking pupils too early on (Jürges/Schneider 2011); furthermore, boys seem to be affected the most by this (Jürges/Schneider 2011). Other studies have pointed out that a low socio-economic background as well as living in rural areas leads to a lower probability of being admitted to upper secondary education (Schnepf 2002). Such inequalities are transposed into the system of vocational education and training and thus may have long-term career ramifications (Beicht/ Walden 2015).

In this regard, our respondents linked pupils in intermediate secondary schools with social decline. However, this differentiation also serves as the basis for a broader chain of association. Deviant behaviour from the "Regelschüler" is not only associated with a somewhat general notion of underperformance, staying behind (in the sense of not leaving the region) or a lack of determination regarding one's self-fulfilment. These pupils also seem to be associated with a variety of criminal behaviour (doing drugs), often socially stigmatised acts (drinking in public, yet not in restaurants) as well as socially stigmatised conditions (unemployed, welfare- 
dependent). Occasionally, such relations are further specified by distinguishing "Regelschüler" from those attending a Special School - i.e. pupils with (learning) disabilities. Of course, this generalisation is not always based on experiences but often is passed on as a visual association between different subjects and groups. This in turn serves feelings of relative deprivation such as when pupils from a Gymnasium complain about the local Regelschule being more technically advanced than their Gymnasium. Intermediate Secondary Schools - beyond mere performance in the context of school marks - can therefore be seen as a widely shared stigma, often used to distinguish oneself from lower-class groups. It is furthermore informed by conditions of scarcity and a prevalent regime of out-migration.

\subsubsection{Identifying problems "elsewhere": Shabby blocks and sweatpants in "a crap city"}

Besides these attempts to draw clear and derogative distinctions between pupils from different schools, references to social misfits - a strategy of deflective localisation - became a common talking point after mentioning the northern parts of the city of Altenburg. Almost any kind of social problems were literally located in the city of Altenburg's northern parts ("Altenburg-Nord"). Though we do not want to play off subjectively and collectively intelligible understandings against assumed objective realities, some additional information should be provided. Altenburg Nord is an urban district built during the 1980 s for about 10,000 people. After re-unification, it shared the fate of other modern urban quarters erected during GDR times. It faced strong out-migration followed by vacancy, decay, and - later on - by the razing of abandoned buildings and reconstruction of others. Mainly owned by a public housing company and a cooperative, it is still associated with downgrading and social deviance. In the following quote, the architectural quality of the environment was taken as a starting point to reflect the "asocial" nature of the area; spatial and social ascriptions were combined:

Moderator: What's your impression of Altenburg and other places?

A: Well, it's kind of asocial, especially when looking at those housing blocks.

B: And take a look at those kids there, they ain't good at anything.

A: They are pretty shabby!

Moderator: The building blocks?

A: Yeah. It has gotten better. [...]

C: I think it's because of all these foreigners living there. And others that receive less money than those who can afford stuff. Maybe, some don't get the support to live in some nicer places, or to provide their kids with better education.

D: Yeah, you often get to see some asocial kids, or youngsters walking around with bottles of beer. Just shabby.

E: And the walls are full of graffiti! (FG_24:630ff.) 
The association between the architectural environment and the social composition of Altenburg's north is seen as being structurally connected, though the connection itself is not clearly specified. Two dimensions of deviance are amalgamated by the participants: unpleasant architecture and (correspondingly) people that are ascribed negative characteristics, both converging within a particular part of the city of Altenburg. Interestingly, foreigners were in general quite rarely mentioned as an indicator for deviance and social decline. However, Altenburg's north was the most frequently mentioned place in the district Altenburger Land during our discussions and equally often described as being the worst one as well. At the same time, Altenburg-Nord epitomises and exemplifies "the other" opposed to a good life, and assembles the respective most despised traits. Its usage often implies an unspecified causality.

However, Altenburg-Nord is just one example of localised stigmas that combine social and spatial characteristics. The whole city of Altenburg can also serve as the entity to blame, being - from the perspective of a pupil from a vocational school - a "Crap city! [...] Altenburg should know that it is a crap city, a dirt city" (FG_12:205ff.). Statements like this were frequent in our material; especially among those seeking more cultural and political diversity. Many of them felt attracted by the city of Leipzig, 50 kilometres away, a city of more than 500,000 inhabitants - in contrast to the 33,000 inhabitants of Altenburg - that is regionally known for its abundant cultural offerings and believed to be politically left-leaning. Furthermore, adolescents from the small towns of Altenburger Land looked down on the city of Altenburg for presenting their everyday problems in an aggravated dimension. However, the logic of despising "the other" - socially and spatially - is also echoed in statements about other small towns in our research area such as Gößnitz and its inhabitants - suggesting that this is widespread rhetorical logic of establishing socio-spatial order:

\begin{abstract}
“When we drive through Gößnitz, most people wear sweatpants, all day long, many are drunk. I don't want to call them misfits, but - yeah - kind of. When driving through Gößnitz, it's kind of a dirty city, as if - since twenty years ago - somebody has stopped taking care of it, as if Gößnitz - now - just vegetates." (FG_20:302)
\end{abstract}

However singular the respective observation is, the label "Gößnitz" entailed numerous ascriptions especially for adolescents from Schmölln, a small town near Gößnitz: an architectural environment perceived as particularly dull as well as the widespread description of social deviance in the Altenburger Land district that we heard quite often. The previous quote from a 16-year old is striking insofar as it presents a rather "standardised" and "sedimented" narrative about small towns that symbolises the social nature of negotiating such stigmas and includes elements beyond his own experience.

However, although some respondents acknowledged that "prejudice" informs the narrative, the overall constructed nature does not surface. Paradoxically, the conditions in Gößnitz are not generally questioned but usually interpreted on the basis of singular - often not necessarily one's own - observations or hear-say, again reproducing the lack of distinction between representation and perceived actuality. 
Instead the adolescents insist that their descriptions do indeed match the respective situation. Paradoxically, they anticipate accusations of prejudice and instantaneously reject them:

"I am in Altenburg quite often. You'll see folks, 16, 17 years old, running around with sweatpants and a 12-year old girlfriend. I just wouldn't want to end up like that. There aren't just a few of them. Just walk through the city. I don't have any prejudices, but you can actually see such folks and tell yourself: I don't want to end up like this." (FG_21:334)

Such localisations of social deviance often served as anchors for more general elaborations on alleged differences between cities and small villages. While the former were associated with noisiness, crimes, anonymity but also leisure activities, the latter was strongly seen to correspond to the need for order, courtesy, rest, a nice environment and family. The city of Altenburg in particular was despised by adolescents from small villages on the basis of more general differentiations between villages and cities:

A: In villages, parents help, it's more about the family. In the city, it's more like, you have your child, but it shouldn't be there, I don't care for it anymore, therefore, it is forced to do everything on its own. Many people live like this, it's getting more and more like that. [...] It's more often in the city, it is more concentrated. [...]

B: If you grow up in a village, you can actually let your child - at 15 or 16 walk the streets after $9 \mathrm{pm}$ without having to be afraid that it has to crawl back to you after being stabbed. (FG 31:655ff.)

Given its exaggerated nature, the latter statement in particular generated intense laughter during the respective discussion. While it was not taken as authentic representation of everyday life in the city of Altenburg, it nevertheless draws on less inflated assumptions about general differences between cities and villages. In sum, social deviance - as articulated in widely shared stigmas - is frequently connected to specific places; they are not only seen as the places where such behaviour happens. Instead, they persistently coalesce with such ascriptions and - as seen in the examples of Gößnitz and Schmölln - are able to retain those associations beyond a specific group or age band. Furthermore, stigmatised places inherit the properties of the stigma, which itself feeds on authentic and remote conveyed experiences. These aspects, however, are only occasionally and partially reflected by the adolescents. Again, "the drug problem" that was identified as a main marker of "the outsider's image" of Altenburg was actualised when the discussion turned to Altenburg-Nord, the place that was repeatedly identified as the hive of drug users:
A: That's an area nobody wants to go to. [...] All these freaky kids [...] Folks who just blunder all day long.
B: There are druggies!
A: Folks that destroy everything. Drugs and everything. That's Nord; it's the worst. 


\section{B: People are getting killed there!}

A: You can even hear gunshots at night. (FG_31:590ff.)

In the eyes of young people, Nord has become the (clearly) defined projection screen for what is going wrong with some of the youth. Yet, not everyone had authentic experiences with Nord. Instead, discussants often relied on hearsay. However, some of our respondents identified the whole city as "plagued by drugs and stuff" and thus in turn as a place where young people feel latently criminalised - just because they are visible in the streets:

A: And most people, especially the youth, suffer from this situation. For example, if you drive through the streets on your mopeds at $11 \mathrm{pm}-$ you will most often get stopped and searched.

Moderator: By the police?

A: Yeah. They definitely get tough with that! And many have to suffer from it, many who don't do drugs. (FG_31:608ff.)

Such incidents catalyse processes of projection, epitomising the inevitability of grappling with the ubiquitous presence of drugs in one's everyday life. On the one hand, our respondents identify drug abuse and abusers in their everyday lives. On the other hand, they also feel the power of stigmatising representations on themselves. Drug abuse, as such, has become more than a localised narrative apart from social actuality; it becomes everyday reality. This, of course, involves assumptions about the mechanisms leading to drug abuse that in turn reveal prevalent stigmas:

"You have to demonstrate that - you know - it could make you die at a younger age, or that you lower yourself, that you aren't able to make progress in life. [...] You know, I think that it's especially the dumber people, who are not that intelligent." (FG_23:655)

In this view, doing drugs means a lack of progress. Such attempts to make causal sense of what they know reveal logic of deflection; the stigma of abusing drugs is seen to involve only specific groups. Characterising druggies against this background illuminates the associations involved in the social negotiation of causality related to drug abuse. Thus, not only what one does or represents is judged as being deviant, but also what one aspires to do - and this is understood as being closely linked to one's abode. For instance, one of our respondents pointed to a close and almost causal relation between social deviance, drug abuse and specific - though not clearly named - places:

"The unemployed parental home is the reason. It's in those parts of the city where many welfare-dependent people live [...] the under-privileged families with disadvantaged children slipping off into certain groups, and getting their influence from them." (FG_23:675)

Here, deviant conditions are not only socially specified but enclosed in specific areas. Furthermore, this narrative represents widely shared and articulated convic- 
tions about alleged connections of cause and effect. Quite frequently, adolescents discussed the lack of leisure and job opportunities in the region, especially highlighting ever-present boredom and a lack of prospects for those living and staying in the region, contributing to a generally negative image of the situation in the Altenburger Land district: "You just have to smoke pot to bear all this here" (FG_16:997). However, it also mirrors hegemonic narratives about peripheralised regions lacking the ability to compete against - mostly - cities that are able to offer jobs and activities satisfying a variety of interests and orientations. Narratives of boredom are thereby incorporated into intra-regional stigmas about specific groups of people and the places they are assumed to live.

\subsection{3 "I didn't know that." Negotiating the dangerous Nord}

As shown above, stigmatisation is a hierarchical condition; although there are a number of negative stigmas referring to the region and to the city of Altenburg, the northern part of the city serves as a projection screen for the most negative phenomena. It is not only associated with drugs but also with crime in general reaching so far as to pose an everyday threat to anyone. Social and spatial characteristics both constitute the stigma and contribute to a - sometimes fuzzy - feeling of being threatened. Astoundingly, the following quote shows a rare but important contestation as nobody seems to agree on the everyday presence of knives in Nord:

A: For example Altenburg-Nord. Everyone knows it. [...] Many call it misfit's quarter, because in Nord really everyone carries knives.

Moderator: Really? Everyone carries knives?

A: Well, no idea ...

$B$ : I didn't know that.

C: Me neither!

A: Well, for example a friend of mine was severely threatened with a knife and a weapon. And he lives there, and he often hears gunshots in the evening. (FG_24:588ff.)

While such a claim seems to be exaggerating singular hearsay, it follows a consistently extreme perspective on Altenburg-Nord. Nevertheless, opposition to a manifest stigmatisation as in the quote above allows space not only for legitimising narratives but also provides insights into the mechanisms of negotiating stigmas. We occasionally encountered pupils debating whether or not the negative depiction of Altenburg-Nord fitted their own experiences. However, they often ignored each other's comments about "the North" as a general socio-spatial category. Instead, it has led them to re-entitise their comments - from a negative area to specific inhabitants - allegedly in order to create compatibility. Generally, there were numerous occasions where differing associations clashed but underwent re-interpretations using the aforementioned deflective strategies of specification and localisation. Often, such incidents had to be explicitly enforced by the moderator, encouraging 
the participants to discuss each other's perspective. This way, a somewhat causal connection between social and spatial ascriptions was dissected. Nevertheless, it always seemed forced and provided just a temporary differentiation as shortly after both dimensions were often re-associated. Social negotiation in this sense doesn't mean that people interact and deliberately argue with each other. Instead, the negotiation of stigmas consists of repetitive statements, only occasionally taking note of each other if conflicting.

The logic of convergent narratives based on social as well as spatial topoi is not restricted to Altenburg-Nord but, instead, a general pattern that has been observed especially in declining neighbourhoods and towns (e.g. Howarth 2002). Once (and as long as) accepted as true, some of our respondents started to explain why deviant behaviour and social problems necessarily coincide in this place and how it is reproduced again and again. Assumed causal mechanisms working behind the scenes - as articulated by a female pupil from a rural intermediate secondary school with regard to Altenburg-Nord - are part of a narrative that legitimises socio-spatial stigmatisation: ${ }^{5}$

"Well, it is the upbringing, because, I think, the parents living there. I don't want to claim that everybody's that way in Nord, that everybody is violent and stuff, but if you grow up there, and the parents, I mean, are welfare dependents and never leave for work, only yell at their child, or beat the child, then, I think, it will not become a really nice person like us." (FG_31:623)

Negotiations of stigmas in such a way involve converging pejorative narratives that include a set of generalised negative social characteristics, a place to which these traits are attributed and sometimes diverging, yet frequently implied, assumptions about possible explanations. Such self-consistent narratives seem to be remarkably persistent in their general logic. Apparently, the moderator's occasional attempts to address its particular and paradoxical nature couldn't break the logic of stigmatisation:

Moderator: This place doesn't sound like I would want to go there! [...]

A (quietly): But it is just another image!

Moderator: I'd like to hear that.

A: Well, it is just another image. Because normal people do live there, in normal houses. It's not that everyone is like that. [...]

Moderator: I assume that we can all agree that not everyone runs around in Altenburg-Nord carrying knives or a gun.

A (laughing): Right!

B: [...] My granny lives in Nord.

5 For a discussion of corresponding perspectives on the impact of one's upbringing for future orientations see Meyer/Miggelbrink 2015. 


\section{Moderator: Well, from a scientific perspective, let's check: Has your granny got knives or a gun? [...] \\ B: No. (FG_24:601ff.)}

While the moderator interrogated a discussant's statement and pressed the group to differentiate such generalising statements, it didn't have much impact. Although the topic changed further on - from weapons to deviance - the logics of deflective specification and localisation did not. The moderator's provocation had led to attempts to re-validate aforementioned statements. Still, the association between generalised social ascriptions and the place proves to be hegemonic, only giving way to detailing the location regarding its architectural characteristics. Correspondingly, the cause of the asocial nature of Nord is now attributed to the housing blocks. Apparently, the underlying conditions of stigmatisation are remarkably persistent in the face of contrasting views as - to our astonishment - such incidents did not induce reflections about the validity of prevalent representations.

\subsection{Stigmatisation and migratory decision-making}

Given the ubiquitous negative ascriptions of the Altenburger Land district and some of its cities, it seems important to illuminate the everyday relevance of such discourses: Considering the age of our respondents, the most urgent and inevitable decision emerging in their near future is related to the respective career path. While some mention their determination to stay in the district and take up a job or pursue an Abitur (equalling an "A-Level"), others are undecided and grapple with the decision. Some even present themselves stoically as logical beings, determined to walk their career path, regardless of what sacrifices might come. As heterogeneous such individual perspectives are, for those who are inclined to migrate elsewhere a repetitive association between leaving and self-fulfilment can be observed:

"It is quite an easy decision: I always have the feeling that if I returned to this place, I would have failed a bit." (FG_20:161)

Notwithstanding such pointed statements, it is by no means a simple but rather a highly complex decision with many career paths to choose from, and with respect to how the decision-making process unfolds individually. Despite the above discussed negative representations of the district, we met adolescents who were not eager to leave their home, but were indeed determined to stay. However, these cases were often related to actual job-offers from local or regional companies, or to the emotions with regard to leaving their family, their friends or the environment the adolescents are used to. Staying, as it were, happens due to what satisfies the personal needs of those on the verge of taking off into adulthood. And as mentioned before, a general sense about a preferred concept of life usually resonates: 
"If you have no one, no friends and everything, but lots of money, what kind of life is that? Would you be happy if you had, for example, three cars there but no contact to your family and no friends? I don't think so." (FG_14: 497ff.)

The most interesting aspect of comparing (potential) stayers and leavers is that they all ponder their migratory considerations on similar aspects: family, friends, job, wages, perception of the Altenburger Land and perceptions of the respective place they consider relocating to. However, how they weigh these criteria in the face of migratory considerations remains highly subjective, yet ultimately decisive. For instance, most adolescents contemplating staying did indeed acknowledge the aforementioned negative depictions of the Altenburger Land. Yet, they decided to disregard them in favour of other factors (e.g. social ties, nature and quiet environment).

On the other hand, for those determined to leave the region, the widely shared negative impressions about the Altenburger Land district do seem to dominate migratory considerations:

"The whole environment [...] decays more and more. [...] There are so many folks not having any work. They belong to an underclass, the lowest level.

And that is a level which - I think - is not something I would want to witness everyday on my way to work." (FG_17:225).

There is, however, a multitude of criteria that seem to inform our respondents' considerations. This manifold has been tackled by accounts of migration happening in a specific "social, economic and political context which is largely common to all members of the community" and that ultimately informs adolescent migration (see Carling 2002: 17). For our example, most of these criteria match the specifics of the main stigmas floating around in the region, such as unemployment, drugs, crime, asocial folks as well as the perception of architectural characteristics:

"You just have to walk through the town twice, and you've virtually seen it all. From then on, you can make up your own mind: Here, it is grey and dull; there, it is grey and dull. There are druggies everywhere. And that is why you just want to leave!" (FG_12:478)

Such negative statements and contrasting examples expressed elsewhere in the discussions exist in different shapes, often unconnected, leading to the assumption that they are of different significance to the adolescents. There is, however, a quite similar, repetitive logic of how decision-making is made intelligible: It does not seem to be crucial negative traits associated with specific places are weighted. Instead, perceptions and experiences, that have been continuously repeated, collectively reinforced and thus became firmly established, quite frequently provided the grounds and the rationalisation for a particular decision (especially to out-migrate). Migratory decisions, so it seems, are often closely tied to assumptions about a good life and depend on the subjective significance of specific criteria that may or may not prove to be pivotal for the ultimate decision whether to migrate or not. Furthermore, they are in one way or another informed by general discourses related 
to their home region. These findings mirror similar empirical accounts of migratory decision-making under the impression of regional discourses about poverty (e.g. Carling 2002) or the expectation that students gain international experience by studying in certain countries (e.g. Collins et al. 2014).

\section{Discussion and Conclusion}

In sum, we conclude a widely shared practice of drawing mental boundaries in a region facing socio-economic decline and negative demographic prospects. Here, places and people are not only constructed as distinct and different but are, moreover, clearly defined as the deviant others that differ substantially from one's own social and spatial normality. Specifically, this normality is strongly related to achievements that defy regional precarity. Three conclusions can be extrapolated from this:

First, socio-economic circumstances inform regional processes of stigmatisation, ultimately leading to further devaluating processes. However theoretically grounded such a claim is, we found empirical evidence in deflective strategies of specification and localisation of deviance that correspond to the conceptual assumptions elaborated on in section 2.2.

Second, these rhetoric strategies have to be understood as symptoms of attributional ambiguity: Though young people felt "somehow" addressed by a negative image, they eagerly tried to - socially and spatially - identify the problems "elsewhere." Hence, these strategies are ways of transforming general pejorative labels for groups and people into intra-regionally assignable labels that specify and localise deviance and reassure belonging and non-belonging to the labelled entities.

Third, the practice of blaming the stigma is not always directly observable as the reflection of stigmatisation has not reached the point of questioning the validity of its logic. However, the perceived - stigmatised - social condition did indeed play a role. Especially for adolescents, it is not about facts and figures when it comes to the decision whether to migrate or not. Rather, their family, their friends and acquaintances constitutes a particular regime of knowledge. We cannot, however, conclude that socio-spatial stigmas determine the wish to migrate. As a hegemonic narrative about assumed social conditions, stigmatisation has a potential efficacy for the respective subjects. Stigmas may influence decisions, stigmas may be ignored and be irrelevant, but they may as well be identified as not matching one's individual perceptions. However, stigmas are part - although allegedly not the driver - of out-migration, entangled in such collective practice regimes. Furthermore, they are symptoms of peripheralisation as they draw on socio-economic criteria but simultaneously entail discursive concomitants (see Meyer/Miggelbrink 2013) - namely rhetorical logics, deflective specifications and localisations.

Our findings provide the grounds for stressing the need to consider the sociogeographic and socio-psychological implications of peripherality. When integrating the economic, demographic as well as discursive aspects of regional precarity, the need to fathom its social ramifications - for example regarding social boundary 
making - becomes inevitable. Furthermore, knowledge about such regimes of stigmatisation is able to illuminate the complex dynamics of migratory decision-making.

Insofar, our findings contribute to debates on territorial and socio-spatial stigmatisation, and, specifically, to research on the structural aspects of social boundary making accompanied by logics of inclusion and exclusion (see e.g. Bude 2008: 53). Moreover, we are able to elaborate further on the role of discursive phenomena in processes of peripheralisation (see e.g. Meyer/Miggelbrink 2013), a dimension that has not gotten much attention in debates on the relational making of place and regions so far. Finally, in the wake of supplying further insights into the role of stigmatisation in migratory considerations, we are able to supplement existing empirical findings in the debate on post-rational migration (e.g. Collins et al. 2014).

\section{References}

Amin, Ash 2004: Regions Unbound: Towards a new Politics of Place. In: Geografiska Annaler: Series B - Human Geography 86,1: 33-44.

Anhut, Reimund 2008: Konflikttheorie der Desintegrationstheorie. In: Bonacker, Thorsten (Ed.): Sozialwissenschaftliche Konflikttheorien. Eine Einführung. Wiesbaden: Springer-VS: 381-408.

Anhut, Reimund; Heitmeyer, Wilhelm 2000: Desintegration, Konflikt und Ethnisierung. Eine Problemanalyse und theoretische Rahmenkonzeption. In: Heitmeyer, Wilhelm; Anhut, Reimund (Eds.): Bedrohte Stadtgesellschaft. Soziale Desintegrationsprozesse und ethnisch-kulturelle Konfliktkonstellationen. Konflikt- und Gewaltforschung. Weinheim und München: Juventa: 17-75.

Attia, Iman 2013: Das Konzept der "gruppenbezogenen Menschenfeindlichkeit". Einige kritische Anmerkungen. In: Soziologische Revue 36,1: 3-9 [doi: 10.1524/srsr.2013.0002].

Barlösius, Eva; Neu, Claudia 2008: Territoriale Ungleichheit: Eine spezifische Ausprägung räumlicher Ungleichheit. In: Berlin-Brandenburgische Akademie der Wissenschaften (BBAW) (Ed.): Peripherisierung - eine neue Form sozialer Ungleichheit? Berlin: 17-24.

BBSR (Bundesinstitut für Bau-, Stadt- und Raumforschung) 2015: Wachsen oder schrumpfen? In: BBSR-Analysen Kompakt 12/2015 [URL: http://www.bbsr.bund. de/BBSR/DE/Veroeffentlichungen/AnalysenKompakt/2015/DL_12_2015.pdf? blob=publicationFile\&v $=3,11.06 .2016]$.

Beetz, Stephan 2008: Peripherisierung als räumliche Organisation sozialer Ungleichheit. In: Barlösius, Eva; Neu, Claudia (Eds.): Peripherisierung - eine neue Form sozialer Ungleichheit? Berlin: Berlin-Brandenburgische Akademie der Wissenschaften: 7-16.

Beicht, Ursula; Walden, Günter 2015: How socially selective is the German system of initial vocational education and training? Transitions into initial vocational training and the influence of social background. In: Journal of Vocational Education \& Training 67,2: 235-255 [doi: 10.1080/13636820.2014.983955].

Bude, Heinz 2008: Die Ausgeschlossenen. Das Ende vom Traum einer gerechten Gesellschaft. München: Carl Hanser Verlag.

Bürk, Thomas 2012: Gefahrenzone, Angstraum, Feindesland: stadtkulturelle Erkundungen zu Fremdenfeindlichkeit und Rechtsradikalismus in ostdeutschen Kleinstädten. Münster: Verlag Westfälisches Dampfboot. 
Bürk, Thomas 2013: Voices from the Margin: The Stigmatization Process as an Effect of Socio-Spatial Peripheralization in Small-Town Germany. In: Fischer-Tahir, Andrea; Naumann, Matthias (Eds.): Peripheralization: The Making of Spatial Dependencies and Social Injustice. Wiesbaden: Springer-VS: 168-186.

Bürk, Thomas; Beißwenger, Sabine 2013: Stigmatisierung von Städten. In: Bernt, Matthias; Liebmann, Heike (Eds.): Peripherisierung, Stigmatisierung, Abhängigkeit? Wiesbaden: Springer-VS: 125-145.

Camp, D.L; Finlay, W.M.L; Lyons, E. 2002: Is low self-esteem an inevitable consequence of stigma? An example from women with chronic mental health problems. In: Social Science \& Medicine 55,5: 823-834 [doi: 10.1016/S0277-9536(01)00205-2].

Carling, Jørgen 2002: Migration in the age of involuntary immobility: Theoretical reflections and Cape Verdean experiences. In: Journal of Ethnic and Migration Studies 28,1: 5-42 [doi: 10.1080/13691830120103912].

Cohen, Nir 2013: Territorial stigma formation in the Israeli city of Bat Yam, 1950-1983: planning, people and practice. In: Journal of Historical Geography 39: 113-124 [doi: 10.1016/j.jhg.2012.07.004].

Collins, Francis L. et al. 2014: Mobility and desire: International students and Asian regionalism in aspirational Singapore. In: Discourse: Studies in the Cultural Politics of Education 35,5: 661-676 [doi: 10.1080/01596306.2014.921996]

Crocker, Jennifer 1999: Social Stigma and Self-Esteem: Situational Construction of Self-Worth. In: Journal of Experimental Social Psychology 35,1: 89-107 [doi: 10.1006/ jesp.1998.1369].

Crocker, Jennifer; Major, Brenda 1989: Social stigma and self-esteem: The self-protective properties of stigma. In: Psychological Review 96,4: 608-630 [doi: 10.1037/0033295X.96.4.608].

Crocker, Jennifer; Major, Brenda 2003: The Self-Protective Properties of Stigma: Evolution of a Modern Classic. In: Psychological Inquiry 14,3-4: 232-237 [doi: 10.1080/1047840X.2003.9682885].

Dando, Christina E. 2009: Deathscapes, topocide, domicide. The Plains in contemporary print media. In: Great Plains Quarterly 29, paper 1198: 94-119.

Decker, Oliver; Weißmann, Marliese; Rothe, Katharina 2009: „Hartz 4" und Arbeitslosigkeit in Gruppendiskussionen - Zwischen autoritärer Aggression und masochistischer Resignation. In: Psychoanalyse - Texte zur Sozialforschung 22,1: 45-70.

Endrikat, Kirsten 2006: Jüngere Menschen. Größere Ängste, geringere Feindseligkeit. In: Heitmeyer, Wilhelm (Ed.): Deutsche Zustände. Folge 4. Frankfurt am Main: Suhrkamp: 101-114.

Goffman, Erving 1974: Stigma. Notes on the management of spoiled identity. New York: J. Aronson.

Greitmeyer, Tobias 2008: Sich selbst erfüllende Prophezeiungen. In: Petersen, Lars-Eric (Ed.): Stereotype, Vorurteile und soziale Diskriminierung. Theorien, Befunde und Interventionen. Weinheim/Basel: Beltz, PVU: 80-87.

Hacking, lan 1995: The looping effects of human kinds. In: Sperber, Dan; Premack, David; Premack, Ann James (Eds.): Causal Cognition: A Multidisciplinary Debate. Oxford: Clarendon Press: 351-383.

Haegeler, Thomas 2015: Polizei und Rathauschef nehmen Crystal-Schriftzug gelassen. In: Osterländer Volkszeitung, 17.04.2015. 
Hannem, Stacey; Bruckert, Chris 2012: Concluding Thoughts. Academic Activism: A Call to Action. In: Bruckert, Chris; Hannem, Stacey (Eds.): Stigma revisited. Implications of the mark. Ottawa: University of Ottawa Press: 176-182.

Härtel-Petri, Roland; Haupt, Heiko 2014: Crystal Meth: Wie eine Droge unser Land überschwemmt. München: Riva.

Heitmeyer, Wilhelm 2006: Gruppenbezogene Menschenfeindlichkeit. Gesellschaftliche Zustände und Reaktionen in der Bevölkerung aus 2002 bis 2005. In: Heitmeyer, Wilhelm (Ed.): Deutsche Zustände. Folge 4. Frankfurt am Main: Suhrkamp: 15-36.

Heitmeyer, Wilhelm 2008: Die Ideologie der Ungleichwertigkeit. Der Kern der gruppenbezogenen Menschenfeindlichkeit. In: Heitmeyer, Wilhelm (Ed.): Deutsche Zustände. Folge 6. Frankfurt am Main: Suhrkamp: 36-43.

Heitmeyer, Wilhelm 2012: Gruppenbezogene Menschenfeindlichkeit in einem entsicherten Jahrzehnt. In: Heitmeyer, Wilhelm (Ed.): Deutsche Zustände. Folge 10. Frankfurt am Main: Suhrkamp: 15-40.

Heitmeyer, Wilhelm; Anhut, Reimund 2000: Desintegration, Konflikt und Ethnisierung. Eine Problemanalyse und theoretische Rahmenkonzeption. In: Heitmeyer, Wilhelm; Anhut, Reimund (Eds.): Bedrohte Stadtgesellschaft. Soziale Desintegrationsprozesse und ethnisch-kulturelle Konfliktkonstellationen. Konflikt- und Gewaltforschung. Weinheim: Juventa: $17-75$.

Heitmeyer, Wilhelm et al. 2009: Gruppenbezogene Menschenfeindlichkeit und bürgerschaftliches Engagement gegen den Rechtsextremismus in der Stadt Altenburg. Sozialraumanalysen zum Zusammenleben vor Ort. Bielefeld.

Hohmeier, Jürgen 1975: Stigmatisierung als sozialer Definitionsprozess. In: Brusten, Manfred; Hohmeier, Jürgen (Eds.): Stigmatisierung. Zur Produktion gesellschaftlicher Randgruppen. Kritische Texte: Sozialarbeit, Sozialpädagogik, soziale Probleme. Neuwied: Luchterhand: 5-24.

Howarth, Caroline 2002: 'So, you're from Brixton?': The struggle for recognition and esteem in a stigmatized community. In: Ethnicities 2,2: 237-260 [doi: $10.1177 / 1468796802002002658]$

Hüpping, Sandra; Reinecke, Jost 2007: Abwärtsdriftende Regionen. Die Bedeutung sozioökonomischer Entwicklungen für Orientierungslosigkeit und Gruppenbezogene Menschenfeindlichkeit. In: Heitmeyer, Wilhelm (Ed.): Deutsche Zustände. Folge 5. Frankfurt am Main: Suhrkamp: 77-101.

IWConsult (Institut der deutschen Wirtschaft Köln Consult GmbH) 2014: "Regionalranking 2014" [URL: http://www.iwconsult.de/regional/, 29.01.2016].

Jones, Gill 1999: 'The Same People in the Same Places'? Socio-Spatial Identities and Migration in Youth. In: Sociology 33,1: 1-22 [doi: 10.1177/S0038038599000012].

Jürges, Hendrik; Schneider, Kerstin 2011: Why Young Boys Stumble: Early Tracking, Age and Gender Bias in the German School System. In: German Economic Review 12,4: 371-394 [doi: 10.1111/j.1468-0475.2011.00533.x]

Kaiser, Cheryl R.; Miller, Carol T. 2003: Derogating the Victim: The Interpersonal Consequences of Blaming Events on Discrimination. In: Group Processes \& Intergroup Relations 6,3: 227-237 [doi: 10.1177/13684302030063001].

Klauer, Karl Christoph 2008: Soziale Kategorisierung und Stereotypisierung. In: Petersen, Lars-Eric (Ed.): Stereotype, Vorurteile und soziale Diskriminierung. Theorien, Befunde und Interventionen. Weinheim/Basel: Beltz, PVU: 23-32. 
Kühn, Manfred 2015: Peripheralization: Theoretical Concepts Explaining SocioSpatial Inequalities. In: European Planning Studies 23,2: 367-378 [doi: 10.1080/09654313.2013.862518].

Kühn, Manfred; Weck, Sabine 2013: Peripherisierung - ein Erklärungsansatz zur Entstehung von Peripherien. In: Bernt, Matthias; Liebmann, Heike (Eds.): Peripherisierung, Stigmatisierung, Abhängigkeit? Wiesbaden: Springer VS: 24-46.

Major, Brenda; Quinton, Wendy J.; Schmader, Toni 2003: Attributions to discrimination and self-esteem: Impact of group identification and situational ambiguity. In: Journal of Experimental Social Psychology 39,3: 220-231 [doi: 10.1016/S0022-1031(02)00547-4].

Mansel, Jürgen; Kaletta, Barbara 2009: Desintegrationsprozesse, Anerkennungsprobleme und Gruppenbezogene Menschenfeindlichkeit. Ein Ost-West Vergleich. In: Heitmeyer, Wilhelm (Ed.): Deutsche Zustände. Folge 7. Frankfurt am Main: Suhrkamp: 73-92.

Mansel, Jürgen; Spaiser, Viktoria 2010: Ängste und Kontrollverluste. Zusammenhänge mit Gruppenbezogener Menschenfeindlichkeit. In: Heitmeyer, Wilhelm (Ed.): Deutsche Zustände. Folge 8. Frankfurt am Main: Suhrkamp: 49-71.

Massey, Doreen 1993: Power-geometry and a progressive sense of place. In: Bird, Jon et al. (Eds.): Mapping the futures. London: Routledge: 59-69.

Meyer, Frank; Miggelbrink, Judith 2013: The Subject and the Periphery: About Discourses, Loopings and Ascriptions. In: Fischer-Tahir, Andrea; Naumann, Matthias (Eds.): Peripheralization. Wiesbaden: Springer-VS: 207-223.

Meyer, Frank; Miggelbrink, Judith 2015: Subjektivität und Kausalität in der Migration(sforschung) - Annäherungen an Rationalisierungen von Migrationsentscheidungen in schrumpfenden Regionen. In: Raumforschung und Raumordnung 73,1: 17-30 [doi: 10.1007/s13147-014-0319-2].

Miggelbrink, Judith; Meyer, Frank 2015a: Spuren medialer räumlicher Repräsentationen in den Wahrnehmungen von Subjekten - Ansatzpunkte zur Analyse. In: Geographische Zeitschrift 103,4: 202-216 [in press].

Miggelbrink, Judith; Meyer, Frank 2015b: Lost in complexity? Researching the role of socio-spatial ascriptions in the process of peripheralization. In: Lang, Thilo et al. (Eds.): Understanding Geographies of Polarization and Peripheralization: Perspectives from Central and Eastern Europe and Beyond. Basingstoke: Palgrave Macmillan: 62-79.

Paasi, Anssi 2013: Regional Planning and the Mobilization of 'Regional Identity': From Bounded Spaces to Relational Complexity. In: Regional Studies 47,8: 1206-1219 [doi: 10.1080/00343404.2012.661410].

Petzke, Martin; Endrikat, Kirsten; Kühnel; Steffen M. 2007: Risikofaktor Konformität. Soziale Gruppenprozesse im kommunalen Kontext. In: Heitmeyer, Wilhelm (Ed.): Deutsche Zustände. Folge 5. Frankfurt am Main: Suhrkamp: 52-76.

Pile, Steve 2008: Where is the Subject? Geographical Imaginations and Spatializing Subjectivity. In: Subjectivity 23,1: 206-218 [doi: 10.1057/sub.2008.9].

Pinel, Elizabeth C. 1999: Stigma consciousness: The psychological legacy of social stereotypes. In: Journal of Personality and Social Psychology 76,1: 114-128 [doi: 10.1037/0022-3514.76.1.114].

Pinel, Elizabeth C.; Bosson, Jennifer K. 2013: Turning Our Attention to Stigma: An Objective Self-Awareness Analysis of Stigma and Its Consequences. In: Basic and Applied Social Psychology 35,1: 55-63 [doi: 10.1080/01973533.2012.746593]. 
PoSCoPP (collective authors) 2015: Understanding New Geographies of Central and Eastern Europe. In: Lang, Thilo; Henn, Sebastian et al. (Eds.): New Geographies of Central and Eastern Europe. Socio-Spatial Polarization and Peripheralization in a Rapidly Changing Region. Houndsmill, Basinstoke: Palgrave: 1-21. [collective authors: Kornelia Ehrlich, Sebastian Henn, Kathrin Hörschelmann, Thilo Lang, Judith Miggelbrink, Wladimir Sgibnev].

Schneider, Torsten 2008: Social Inequality in Educational Participation in the German School System in a Longitudinal Perspective: Pathways into and out of the most Prestigious School Track. In: European Sociological Review 24,4: 511-526 [doi: 10.1093/ esr/jcn017].

Schnepf, Sylke 2002: A Sorting Hat that Fails? The transition from primary to secondary school in Germany. Florence: UNICEF Innocenti Research Centre.

Schooler, Deborah et al. 2004: Who's That Girl: Television's Role In The Body Image Development Of Young White And Black Women. In: Psychology of Women Quarterly 28,1: 38-47 [doi: 10.1111/j.1471-6402.2004.00121.x].

Schreiber, Verena 2005: Regionalisierungen von Unsicherheit in der Kommunalen Kriminalprävention. In: Glasze, Georg; Rolfes, Manfred; Pütz, Robert (Eds.): Diskurs - Stadt - Kriminalität. Städtische (Un-)Sicherheiten aus der Perspektive von Stadtforschung und Kritischer Kriminalgeographie. Bielefeld: Transcript Verlag: 59-104.

Schwarzenberg, Tom 2016: Jugendliche Lebenswelten in peripherisierten Regionen. Ein subjektorientierter Zugang durch Gruppendiskussionen und qualitative Inhaltsanalyse. In: Wintzer, Jeannine (Ed.): Qualitative Methoden in der Sozialforschung. Forschungsbeispiele von Studierenden für Studierende. Berlin/Heidelberg: Springer Spektrum: 117-126.

Shields, Rob 1991: Places on the Margins. Alternative geographies of modernity. London/New York: Routledge.

Tekin, Serife 2014: The Missing Self in Hacking's Looping Effects. In: Kincaid, Harold; Sullivan, Jacqueline A. (Eds.): Classifying psychopathology. Mental kinds and natural kinds. Philosophical psychopathology. Cambridge/London: The MIT Press: 227-256.

Thrift, Nige/ 1999: Steps to an ecology of place. In: Massey, Doreen; Allen, John; Sarre, Philip (Eds.): Human Geography Today. Cambridge: Polity Press: 295-321.

Wacquant, Loic 2007: Territorial Stigmatization in the Age of Advanced Marginality. In: Thesis Eleven 91,1: 66-77 [doi: 10.1177/0725513607082003].

Wacquant, Loic 1997: Three Pernicious Premises in the Study of the American Ghetto. In: International Journal of Urban and Regional Research 21,2: 341-353 [doi: 10.1111/14682427.00076].

Weichhart, Peter; Weiske, Christine; Werlen, Benno 2006: Place Identity und Images. Das Beispiel Eisenhüttenstadt. Wien: Institut für Geographie und Regionalforschung der Universität Wien.

Wiest, Karin 2015: Migration and everyday discourses: Peripheralisation in rural Saxony-Anhalt from a gender perspective. In: Journal of Rural Studies [doi: 10.1016/j. jrurstud.2015.03.003].

Wiest, Karin; Leibert, Tim 2013: Wanderungsmuster junger Frauen im ländlichen Sachsen-Anhalt - Implikationen für zielgruppenorientierte Regionalentwicklungsstrategien. In: Raumforschung und Raumordnung 71,6: 455-469 [doi: 10.1007/s13147-0130257-4].

Wolf, Karina; Schlüter, Elmar; Schmidt, Peter 2006: Relative Deprivation. Riskante Vergleiche treffen schwache Gruppen. In: Heitmeyer, Wilhelm (Ed.): Deutsche Zustände. Folge 4. Frankfurt am Main: Suhrkamp: 67-85. 
Zimmerbauer, Kaj; Paasi, Anssi 2013: When old and new regionalism collide: Deinstitutionalization of regions and resistance identity in municipality amalgamations. In: Journal of Rural Studies 30: 31-40 [doi: 10.1016/j.jrurstud.2012.11.004].

Frank Meyer $(\bowtie)$, Dr. Judith Miggelbrink, Tom Schwarzenberg. Leibniz Institute for Regional Geography. Leipzig, Germany. E-mail: F_Meyer@ifl-leipzig.de,

E-mail: J_Miggelbrink@ifl-leipzig.de,E-mail:T_Schwarzenberg@ifl-leipzig.de

URL: https://www.ifl-leipzig.de/de/das-ifl/mitarbeiter/meyer-frank.html

URL: https://www.ifl-leipzig.de/de/das-ifl/mitarbeiter/miggelbrink-judith.html

URL: https://www.ifl-leipzig.de/de/das-ifl/mitarbeiter/schwarzenberg-tom.html 


\section{Appendix: German original quotes}

\section{Chapter 3.2}

\section{FG_21:455}

In Altenburg sind einfach viel zu viele vorpubertäre oder pubertäre Jugendliche, die meinen sie müssen sich zeigen. Da gibt es natürlich coole Leute [...] Und dann gibt es aber auch welche, die willst du einfach nicht wiedersehen. [...] Die sind von der Art ekelhaft und die sind, wenn, weiß ich nicht, wenn denen etwas nicht passt, dann sind die total kirre und drehen frei. Also in Altenburg- Das ist nicht in jeder Stadt so.

\section{FG_16:466ff.}

A: Wir wohnen aber nicht in Altenburg.

B: Ich sag aber mal, also wir sehen uns noch halbwegs als die normale Schicht. Da gibt es aber noch die anderen.

FG_23:441

Drogenhochburg. Geh irgendwo nach Leipzig [...] Gera. Wo kommst du her? Altenburg. Und dann wird halt Altenburg auch ein bisschen so in die Richtung Drogen gedrängt. Also man weiß schon, was hier drinnen abgeht.

\section{Chapter 3.3.1}

FG_17:441ff.

A: Und dann werden auch die Förderschulen zugemacht, da sind dann die Förderschüler mit bei den Regelschülern und dann ist das dort noch katastrophaler. [...] Also manchmal haben die mit uns Sportunterricht und wie die dann die Lehrer runtermachen ...

Moderator: [...] Was ist da der Unterschied, zwischen Regelschule und Gymnasium hier? Wie die Lehrer runtergemacht werden?

B: Erstens das und zweitens ist Regelschule sehr sehr asozial. Also es gibt Ausnahmen, aber das sind ganz wenige. Der Großteil ist wirklich sehr asozial und pöbelt sich gegenseitig an. Da gibt es auch schon öfters mal Prügeleien. 


\section{Chapter 3.3.2}

FG_24:630ff.

Moderator: Was ist denn so euer Eindruck von Altenburg oder von anderen Orten?

A: Naja, es ist teilweise asozial, wenn man da manchmal die Wohnblöcke halt auch sieht.

B: Wenn du die Kinder siehst, die haben doch auch nix drauf.

A: Wie die übelst heruntergekommen sind.

Moderator: Die Wohnblöcke?

A: Ja. Das ist schon ein bisschen besser geworden.

C: Naja, ich bin der Meinung es liegt halt eher daran, dass da viele Ausländer leben. Auch viele, die nicht so viel Geld haben wie vielleicht manch andere, die sich das leisten können. Vielleicht kriegen manche auch nicht so die Unterstützung für irgendetwas, dass sie halt besser wohnen können, oder dass die Kinder vielleicht bessere schulische Ausbildung haben.

D: Naja da sieht man halt auch öfter mal naja eher so asoziale Kinder, oder dann laufen die kleineren mit einer Bierflasche rum. Oder- das ist halt einfach heruntergekommen.

E: Ich finde halt auch, das ist angesprayt, die Hauswände und alles.

FG_12:205ff.

Kackstadt halt. [...] Das kann Altenburg so wissen, dass es eine Kackstadt ist. Es ist eine Drecksstadt.

\section{FG_20:302}

... wenn wir so durchfahren, also die meisten Leute haben irgendwelche Jogginghosen an, den ganzen Tag, und viele sind betrunken. Ich will jetzt nicht Assis sagen, aber so ein bisschen doch schon. Wenn man da durchfährt, es ist irgendwie so eine dreckige Stadt, es ist als ob vor zwanzig Jahren da jemand aufgehört hat sich darum zu kümmern, als ob die jetzt einfach vor sich hinvegetiert.

\section{FG_21:334}

Also ich bin jetzt auch viel in Altenburg und wenn man da so Leute sieht, so 16, 17 und die rennen mit Jogginghosen herum mit einer zwölfjährigen Freundin. Ich will einfach nur nicht so enden. Da gibt es wirklich nicht wenige. Und man muss einfach nur durch den Ort laufen. Also ohne jetzt irgendwie Vorurteile zu haben, aber du siehst Leute, da sagst du dir einfach, so willst du nicht enden. 


\section{FG_31:655ff.}

A: Auf dem Dorf, da ist man mehr, die Eltern helfen mit und so, mehr familiär. Aber in der Stadt ist es mehr zum Beispiel so, man hat halt das Kind, aber es sollte ja nicht da sein, ich kümmere mich nicht darum, dann muss es halt alleine machen. Und das ist halt bei vielen so und das häuft sich dann mehr und mehr. [...] les gibt halt in der Stadt, ist es mehr so weit konzentriert. [...]

B: Wenn wenn man jetzt zum Beispiel auf dem Dorf aufwächst, dann kannst du halt mal dein Kind nach 21 Uhr, wenn es so 15, 16 ist, auch mal auf die Straße lassen, ohne dass du halt Angst haben musst, dass es hier halb abgestochen wieder zurückkriecht.

\section{FG_31:590ff.}

A: Na das ist so ein Gebiet, wo eigentlich keiner hin will. [...] Da rennen die ganzen behinderten Kinder rum. [...] Na es sind halt die, die den ganzen Tag nur scheiße machen.

B: Und Drogenopfer sind da!

A: Die alles kaputt machen, vor allen Dingen Drogen und alles möglich. Da ist Nord halt das, was gerade am schlimmsten betroffen ist.

B: Da werden auch welche umgebracht auf der Straße.

A: Da hörst du auch schon mal schnell paar Schüsse oder so nachts.

\section{FG_31:608ff.}

A: Und die Meisten, halt gerade so jugendmäßig, haben halt darunter zu leiden. Also gerade wenn du mit den Kumpels halt so nach 23:00 Uhr halt mit den Mopeds noch rumfährst, wirst du eigentlich immer angehalten und dann halt durchsucht.

Moderator: Von der Polizei?

A: Ja. Die gehen halt da sehr scharf. Und da haben halt viele darunter zu leiden, die da eigentlich gar nicht beteiligt sind.

\section{FG_23:655}

...halt zeigen, dass man da, was weiß ich, schneller stirbt beziehungsweise total runterkommt, dass man nichts erreicht im Leben. [...] Weil ich denke mal jetzt, dass eher so die ich sage mal dumme Bevölkerung, die nicht so schlau sind 


\section{FG_23:675}

Das arbeitslose Elternhaus sehe ich als Grund. Das sind halt die Stadtbezirke, wo man weiß, da sind viele Hartzer [...] die sozial schwachen Familien, wo die Kinder ziemlich benachteiligt sind, in bestimmte Gruppen abrutschen und da von dort halt auch den Einfluss bekommen

\section{FG_16:997}

Da kannst du bloß noch Kiffen, dass du hier halbwegs alles verträgst.

\section{Chapter 3.3.3}

\section{FG_24:588ff.}

A: Na zum Beispiel Altenburg Nord, also das Viertel da, das kennt man ja auch. [...] Viele nennen es halt auch schon Assiviertel, weil da rennt halt auch wirklich jeder mit irgendeinem Messer rum da.

\section{Moderator: Da rennt jeder mit einem Messer rum?}
A: Naja, keine Ahnung.
$B:$ Das wusste ich nicht.
C: Das wusste ich auch nicht, nein.
A: Naja, zum Beispiel ein Freund von mir wurde da auch schon mal sehr stark bedroht mit einem Messer und einer Waffe und-Der wohnt da in der Nähe, der hört auch abends öfter mal Schüsse.

\section{FG_31:623}

Ja, na auch die Erziehung, weil wenn ich, denke ich mal, jetzt so die Eltern halt mit dort wohnen- Ich will jetzt nicht sagen, dass dort alle so sind, das die halt übelst gewalttätig sind und alles, aber wenn man dort halt jetzt aufwächst und die Eltern halt so, sag ich mal, Hartz 4-Empfänger sind und dann halt nie arbeiten gehen, die ganze Zeit nur ihr Kind anbrüllen beziehungsweise schlagen, dann denke ich mal auch, dass das nicht so ein wirklich netter Mensch wie wir jetzt werden wird.

\section{FG_24:601ff.}

Moderator: Das hört sich nach einem Ort an, wo ich nicht gern hingehen würde. [...]

A: ((leise)) Das ist auch bloß nur ein Image.

Moderator: Das würde ich gerne hören!

A: Na das ist auch bloß nur ein Image, weil da wohnen auch normale Leute in normalen Häusern, das ist nicht so, dass jeder da so rumrennt. [...] 
Moderator: Also ich gehe davon aus, dass wir uns alle einig sind, dass nicht jeder in Altenburg Nord mit einem Messer oder einer Waffe im Anschlag rumrennt.
A: ((belustigt)) Richtig!
B: [...] Meine Oma wohnt da.

Moderator: Okay, und dann müssten wir jetzt aus wissenschaftlicher Sicht testen, hat deine Oma ein Messer oder eine Waffe? [...]

B: Nein.

\section{Chapter 3.4}

\section{FG_20:161}

Und ich habe immer so das Gefühl, wenn ich später mal wieder hier bin, dass ich dann irgendwie so ein bisschen gescheitert bin.

FG_14: 497ff.

Aber wenn du niemanden hast, keine Freunde und alles und hast aber übelst viel Geld, was hast du denn dann für ein Leben? Bist du dann glücklich, wenn du dort, was weiß ich, drei Autos hast und hast aber zu deiner Familie keinen Kontakt und hast keine Freunde? Glaub ich nicht unbedingt.

FG_17:225

Die ganze Umgebung hier [...] verfällt immer mehr. [...] Weil es gibt mittlerweile so viele, die gehen hier einfach nicht arbeiten. Die fallen wirklich mehr in die untere Schicht rein und in die untere Schiene und das ist dann ein Niveau, wo ich mir denke, dass muss ich mir nicht tagtäglich auf einer Arbeit hier irgendwo ansehen.

FG_12:478

Hier gehst du zweimal durch und dann hast du da im Prinzip schon alles gesehen, weil du kannst dir dann eigentlich denken, ja, dort ist es grau und eintönig, dort ist es grau und eintönig, es rennen überall Drogenleute rum. Und da will man einfach nur weg. 


\section{Comparative Population Studies}

WWW.comparativepopulationstudies.de

ISSN: 1869-8980 (Print) - 1869-8999 (Internet)

Published by

Prof. Dr. Norbert F. Schneider

Federal Institute for Population Research D-65180 Wiesbaden / Germany

\section{(cc) BY-SA}

2016

\section{Managing Editor}

Frank Swiaczny

\section{Assistant Managing Editor}

Katrin Schiefer

\section{Copy Editor}

(Selected Articles in German)

Dr. Evelyn Grünheid

\section{Layout}

Beatriz Feiler-Fuchs

E-mail:cpos@bib.bund.de

\section{Scientific Advisory Board}

Paul Gans (Mannheim)

Karsten Hank (Köln)

Johannes Huinink (Bremen)

Michaela Kreyenfeld (Rostock)

Marc Luy (Wien)

Notburga Ott (Bochum)

Peter Preisendörfer (Mainz)

Nikola Sander (Groningen)

Zsolt Spéder (Budapest)

\section{Board of Reviewers}

Martin Abraham (Erlangen)

Laura Bernardi (Lausanne)

Hansjörg Bucher (Bonn)

Claudia Diehl (Konstanz)

Andreas Diekmann (Zürich)

Gabriele Doblhammer-Reiter (Rostock)

Jürgen Dorbritz (Wiesbaden)

Anette Eva Fasang (Berlin)

E.-Jürgen Flöthmann (Bielefeld)

Alexia Fürnkranz-Prskawetz (Wien)

Beat Fux (Salzburg)

Joshua Goldstein (Berkeley)

Sonja Haug (Regensburg)

Hill Kulu (Liverpool)

Aart C. Liefbroer (Den Haag)

Kurt Lüscher (Konstanz)

Emma Lundholm (Umeå)

Nadja Milewski (Rostock)

Dimiter Philipov (Wien)

Roland Rau (Rostock)

Tomáš Sobotka (Wien) Jeroen Spijker (Barcelona)

Olivier Thévenon (Paris)

Helga de Valk (Brussel)

Heike Trappe (Rostock)

Michael Wagner (Köln) 